\title{
Importance of thrombosis and thrombolysis in silent ischaemia: comparison of patients with acute myocardial infarction and unstable angina
}

\author{
Enrique Gurfinkel, Raúl Altman, Alejandra Scazziota, Jorge Rouvier, Branco Mautner
}

\begin{abstract}
Objective-To investigate whether plaque rupture and thrombosis have a role in silent ischaemia as well as in unstable angina.

Design-Prospective analysis of the results of haemostatic diagnostic tests at the moment of developing silent ischaemia at rest.

Setting-Coronary care unit.
\end{abstract}

Patients-22 patients with acute myocardial infarction, 12 patients with symptomatic angina (unstable angina), and $\mathbf{1 0}$ normal volunteers (control group).

Interventions-Continuous cardiac monitoring detected 15 asymptomatic episodes (silent ischaemia) in 6 patients with unstable angina. Blood samples were obtained at admission and when an asymptomatic alteration was detected and 10 minutes later.

Main outcome measures-Comparisons of concentrations of tissue plasminogen activator, urokinase type plasminogen activator, tissue plasminogen activator inhibitor-1, cross-linked fibrin degradation products, von Willebrand factor, and thrombin-antithrombin III complexes in patients and controls at admission; same comparisons in patients with silent ischaemia at the start of an episode and 10 minutes later.

Results-Tissue plasminogen activator concentrations were raised at admission in patients with acute myocardial infarction (mean (SD) 14.2 (6) $\mathrm{ng} / \mathrm{ml}$ ) and in patients with unstable angina $(10 \cdot 1(2 \cdot 5)$ $\mathrm{ng} / \mathrm{ml}$ ) in comparison with controls $(5 \cdot 1$ $(2.7) \mathrm{ng} / \mathrm{ml}, \mathrm{p}<0.01$ and $<0.05$ respectively). There was no differences between the two groups of patients, however. Similar results were observed at the start of a silent ischaemic episode $(9.8(1.9)$ $\mathrm{ng} / \mathrm{ml})$ and 10 minutes later (10.5 (2.9) $\mathrm{ng} / \mathrm{ml}$ ) compared with controls ( $p<$ 0.05). Tissue plasminogen activator inhibitor-1 concentrations were raised in patients with acute myocardial infarction (45.1 (15) $\mathrm{ng} / \mathrm{ml}$ ) compared with volunteers $(20.6(16) \mathrm{ng} / \mathrm{ml}, \mathrm{p}<0.01)$. In patients with silent ischaemia tissue plasminogen activator inhibitor-1 concentrations were slightly but not significantly increased. Concentrations of cross-linked fibrin degradation products (D dimer) increased during unstable angina (2150 (350) $\mathrm{ng} / \mathrm{ml}$ ) and silent ischaemia (2270 (450) $\mathrm{ng} / \mathrm{ml}$ ) compared with the concentrations in volunteers (340 (80) $\mathrm{ng} / \mathrm{ml}$ ) and patients with acute myocardial infarction (310 (120) $\mathrm{ng} / \mathrm{ml}$; p $<0.01$ ).

Conclusions-The results suggest that thrombosis mediates the pathophysiological mechanisms of silent ischaemia and unstable angina.

(Br Heart f 1994;71:151-155)

The hallmark of unstable angina is its unpredictability. Studies using coronary arteriography, angioscopy, and serial reconstruction of the microanatomy all show that thrombosis at the site of ruptured plaque is important in the aetiology of unstable angina. ${ }^{1}$ Episodes of silent ischaemia are more important than symptomatic ischaemia as contributors to total myocardial ischaemia burden. Around $70 \%$ of the ischaemic episodes in patients with coronary artery disease are not associated with angina, ${ }^{2}$ but patients with exercise induced silent ischaemia have a similar prevalence of disease affecting the left main coronary artery and three main vessels to that, in patients with angina but a higher mortality. ${ }^{3}$

Multivariate analyses showed that the presence of silent ischaemia in patients after admission to a coronary care unit was the best predictor of subsequent acute myocardial infarction or the need for angioplasty or bypass surgery. ${ }^{4}$ The prognostic importance of silent ischaemia in patients admitted to hospital with unstable angina prompted us to study the role of thrombotic and fibrinolytic process in these patients. Our goal was to determine whether these processes had a role in silent ischaemia detectable at rest but not induced by stress.

Patients and methods

We studied 10 healthy volunteers, 22 patients with acute myocardial infarction, and 12 patients with unstable angina at rest.

\section{INCLUSION CRITERIA}

Patients with unstable angina were included if they had developed silent ischaemia, were under 75, had angina classified as functional class IV, and had no left bundle branch block or left ventricular hypertrophy with ST segment changes. Patients were excluded if they had angina soon after infarction (starting in the first month after acute myocardial infarction); if they had had drug treatment for 
unstable angina, including heparin; if continuous ST segment electrocardiographic recording had not been started within two hours of admission; if they were receiving concurrent anticoagulant treatment; if they had bleeding diathesis; if they had hepatic, renal, or infectious diseases; if they had undergone any surgical procedure or trauma within the previous 30 days; if they had unstable angina without silent ischaemia; and if they refused to give their informed consent. Unstable angina was defined as at least two episodes of angina at rest before admission. The episodes could be either of new onset or part of a history of stable angina.

BASAL CHARACTERISTICS

The mean age of the 22 patients with acute myocardial infarction was 58.9 years; 16 were men $(73 \%)$ and six women $(27 \%)$. The mean age of the 12 patients with unstable angina was 52.5 years; nine were men $(75 \%)$ and three women $(25 \%)$. The mean age of the 10 normal volunteers was 48.3 years; seven were men $(70 \%)$ and three women $(30 \%)$.

Thirteen of the 22 patients with acute myocardial infarction (59\%) were taking drugs at the time of venepuncture: seven (32\%) were taking $\beta$ blockers, five (23\%) calcium antagonists, five (32\%) enalapril, and two (32\%) aspirin. Five of the patients with unstable angina (42\%) were taking aspirin, two $(17 \%) \beta$ blockers, and three (25\%) long term calciums, antagonists. None of the normal volunteers were given drugs and all of them were asked to stop taking any drugs seven days before taking part in the study.

All patients with acute myocardial infarction and unstable angina received $\beta$ blockers and aspirin (500 mg) after a blood sample was taken. Nitrates were not given during the study to patients with unstable angina. Acute myocardial infarction was excluded by serial assay of plasma creatine kinase concentrations.

\section{DETECTION OF SILENT ISCHAEMIA}

Ischaemic electrocardiographic changes without accompanying symptoms were considered to be silent events. Recordings were begun within two hours of admission to the coronary care unit using a 12 lead electrocardiographic continuous monitor (ELI 100, Physio Control, Mortara Instruments, Milwaukee). This device has been shown to have high sensitivity for the detection of ischaemic alterations in the ST segment. ${ }^{5}$ The monitor scanned the 12 lead electrocardiogram every 20 seconds, storing the information whenever ST segment elevation or depression of more than $0.5 \mathrm{mV}$ occurred 60 ms after the " $\mathrm{J}$ " point in at least two consecutive leads. The alarm mode was programmed to detect any significant alteration in the ST segment and immediately recorded a complete 12 lead electrocardiogram.

Blood samples were obtained before any treatment was started from patients at admission and at the moment of symptomatic events. When the alarm signal detected any shifts in the ST segment greater than $0.5 \mathrm{mV}$, the attending cardiologist confirmed the electrocardiogram had changed without the occurrence of symptoms; a new blood sample was taken during the episode and 10 minutes after to confirm the values obtained previously.

During the same time 22 patients with acute myocardial infarction (less than six hours from the onset of symptoms) were admitted to the study. Blood samples were obtained before any treatment was started. Ten normal volunteers also gave blood samples under basal conditions. Blood was obtained from the antecubital vein and collected in plastic tubes containing sodium citrate $0.11 \mathrm{mmol} / 1(1: 0 \cdot 1 \mathrm{vol} / \mathrm{vol})$, placed in ice and centrifuged within two hours at $1600 \mathrm{~g}$ for 20 minutes in the cold to obtain platelet poor plasma. Platelet poor plasma was aliquoted and frozen in plastic tubes at $-25^{\circ} \mathrm{C}$ until tests were performed. When indicated, in vitro degradation of fibrin was inhibited by addition of aprotinin $300 \mathrm{U} / \mathrm{ml}$ (Trasylol FBA Pharmaceuticals, Germany). To determine tissue plasminogen activator blood was collected on sodium citrate $0.11 \mathrm{mmol} / 1$ acidified with citric acid to $\mathrm{pH} 4 \cdot 0$. Platelets were counted using a flow cytometer (Cellanalyzer Ca 460, Medonic, Sweden). Prothrombin time, activated partial thromboplastin time, clotting factor VIII activity, and thrombin time were measured by standard methods. ${ }^{6}$ Titres of von Willebrand antigen were measured with Laurell's procedure using rabbit antiserum antibody (Dakopatts, Glostrup, Denmark). ${ }^{7}$ Tissue plasminogen activator activity was assayed by a chromogenic method (Spectrolyse reagent, American Diagnostica, Greenwich, Connecticut); tissue plasminogen activator concentration by an enzyme linked immunosorbent assay (ELISA) (Diagnostica Stago, Ansieres, France); tissue plasminogen activator inhibitor-1 (PAI-1) concentration with the Tintelize PAI-1 kit (Biopool, Umea, Sweden); urokinase type plasminogen activator by an immunoabsorbant technique (Chromolize u-PA, Biopool, Umea, Sweden); cross linked fibrin degradation product (D dimer) concentrations by an ELISA (Asserachrom D-DI, Diagnostica Stago, Asnières, France); complexes of thrombinantithrombin III with the Enzygnost-TAT kit (Behringwerke, Marburg, Germany); and ristocetin cofactor according to MacFarlane et al using ristocetin from Lundbeck (Copenhagen, Denmark). ${ }^{8}$

\section{STATISTICAL ANALYSIS}

Data from patients with unstable angina were compared with those from normal volunteers and from patients with acute myocardial infarction. Patients with acute myocardial infarction were also compared with normal volunteers. For unequal variances Cochran's approximate two tailed test for comparing three samples was applied. Thrombotic and fibrinolytic values in patients with unstable angina were also compared with those in 
Table 1 Concentrations of haemostatic factors in normal volunteers and in patients with unstable angina and acute myocardial infarction. Values are means (SD)

\begin{tabular}{|c|c|c|c|c|c|c|}
\hline & \multirow[b]{2}{*}{$\begin{array}{l}\text { Normal volunteers } \\
(n=10)\end{array}$} & \multicolumn{2}{|l|}{ Patients with: } & \multicolumn{3}{|l|}{ p Value } \\
\hline & & $\begin{array}{l}\text { Unstable } \\
\text { angina } \\
(n=6)\end{array}$ & $\begin{array}{l}\text { Myocardial } \\
\text { infarction } \\
(n=22)\end{array}$ & $\begin{array}{l}\text { Unstable } \\
\text { angina v } \\
\text { control }\end{array}$ & $\begin{array}{l}\text { Myocardial } \\
\text { infarction v } \\
\text { control }\end{array}$ & $\begin{array}{l}\text { Unstable angina } \\
v \text { myocardial } \\
\text { infarction }\end{array}$ \\
\hline $\begin{array}{l}\text { Tissue plasminogen activator: } \\
\text { Concentration (ng/ml) } \\
\text { Activity (IU/ml) } \\
\text { Inhibitor-1 (ng/ml) } \\
\text { D dimer (ng/ml) } \\
\text { vWag (\%) } \\
\text { Ristocetin cofactor (\%) } \\
\text { u-PA (ng/ml) } \\
\text { TAT (ng/ml) }\end{array}$ & $\begin{array}{l}5 \cdot 1(2 \cdot 7) \\
1 \cdot 2(0 \cdot 4) \\
20 \cdot 6(15) \\
340 \quad(60) \\
96 \quad(18) \\
90(12) \\
0.5(0 \cdot 2) \\
3 \cdot 4(0.4)\end{array}$ & $\begin{array}{rr}10.1 & (2.5) \\
1.6 & (0.3) \\
30.8 & (15) \\
2150 & (350) \\
104 & (17) \\
80 & (8) \\
0.4 & (0.1) \\
0.5 & (0.8)\end{array}$ & $\begin{array}{cc}14 \cdot 2 & (6 \cdot 0) \\
1.6 & (0.6) \\
45 \cdot 1 & (15) \\
310 & (120) \\
94 & (19) \\
97 & (20) \\
0.6 & (0 \cdot 2) \\
14 & (11)\end{array}$ & $\begin{array}{l}0.05 \\
\text { NS } \\
\text { NS } \\
0.01 \\
\text { NS } \\
\text { NS } \\
\text { NS } \\
0.01\end{array}$ & $\begin{array}{l}0.01 \\
\text { NS } \\
0.01 \\
0.01 \\
\text { NS } \\
\text { NS } \\
\text { NS } \\
0.01\end{array}$ & $\begin{array}{l}\text { NS } \\
\text { NS } \\
\text { NS } \\
\text { NS } \\
\text { NS } \\
0.05 \\
\text { NS } \\
0.01\end{array}$ \\
\hline
\end{tabular}

$\mathrm{D}$ dimer = cross linked fibrin degradation products; $\mathrm{vWag}=$ von Willebrand factor antigen; $\mathrm{u}-\mathrm{PA}=$ urokinase type plasminogen activator; TAT $=$ Thrombin-antithrombin III complexes.

patients with silent ischaemia during an ischaemic episode and ten minutes later. Values were analysed by analysis of variance. The $p$ value was estimated by using $\alpha_{3}$ for each comparison. For equal variances Tukey's procedure was used. Results are expressed as means (SD).

\section{Results}

During a total of 158 hours of continuous electrocardiographic recording (mean of 13.1 hours/patients), 15 episodes of silent ischaemic ST segment change were registered at rest in six patients with unstable angina (five men and one woman, mean age 52.5 years). Four had ST segment elevation and 11 had ST segment depression. The time between admission and the first episode of silent ischaemia was 377 (135) minutes. The mean duration of the asymptomatic episodes was 15 (8) minutes. After the last blood sample was obtained patients were treated with intravenous nitrate at medium doses. Despite this, ST changes recurred on eight occasions. This suggests that vasospasm was an unlikely cause of these episodes of silent ischaemia. ${ }^{9}$ No symptomatic ischaemia occurred during continuous electrocardiographic monitoring.

The differential blood count, platelet count, prothrombin time, activated partial thromboplastin time, clotting factor VIII activity, and thrombin time were normal on admission (data not shown). Tissue plasminogen activator concentrations were raised on admission in patients with unstable angina and during silent ischaemia (table 1) at the

Table 2 Concentrations of haemostatic factors in patients with silent ischaemia. Values are means (SD)

\begin{tabular}{|c|c|c|}
\hline & $\begin{array}{l}\text { During silent } \\
\text { ischaemia } \\
\text { episode } \\
(n=6)\end{array}$ & $\begin{array}{l}\text { After } 10 \\
\text { minutes } \\
(n=6)\end{array}$ \\
\hline $\begin{array}{l}\text { Tissue plasminogen activator: } \\
\text { Concentration (ng/ml) } \\
\text { Activity (IU/ml) } \\
\text { Inhibitor-1 (ng/ml) } \\
\text { D dimer (ng/ml) } \\
\text { vWag (\%) } \\
\text { Ristocetin cofactor (\%) } \\
\text { u-PA (ng/ml) } \\
\text { TAT (ng/ml) }\end{array}$ & $\begin{array}{c}9.8(1.9) \\
1.4(0.4) \\
29.8(16) \\
2270(450) \\
116(15) \\
79(13) \\
0.5(0.05) \\
0.51(0.5)\end{array}$ & $\begin{array}{c}10.5(2.9) \\
1.3(0.2) \\
34.4(19) \\
2150(370) \\
109(18) \\
73(10) \\
0.5(0.08) \\
1.08(1 \cdot 2)\end{array}$ \\
\hline
\end{tabular}

start of an asymptomatic episode or $10 \mathrm{~min}$ utes later than in the controls $(p<0.05)$. Tissue plasminogen activator concentrations were also higher in patients with acute myocardial infarction $(p<0.01)$ than in the controls but the difference between patients with unstable angina and silent ischaemia was not statistically significant. Tissue plasminogen activator inhibitor-1 concentrations were higher in the group with acute myocardial infarction than in the controls $(p<0.01$, table 1). In patients with unstable angina and during silent ischaemia in the other group tissue plasminogen activator inhibitor-1 concentrations at the start of an episode and 10 minutes later were slightly increased but were not significantly higher than in the controls (table 2). D dimer concentrations, an indicator of fibrin breakdown reflecting clot formation and lysis, were within normal limits in the patients with acute myocardial infarction but were increased in patients during unstable angina and during episodes of silent ischaemia ( $p<0.01 v$ controls or acute myocardial infarction). The concentration of thrombin-antithrombin III complexes was increased in patients with acute myocardial infarction $(p<0.01 v$ control (table 1) but not in unstable angina or silent ischaemia. No differences between the episodes of unstable angina and silent ischaemia were found in any of the variables measured (table 2).

\section{Discussion}

Angiographic and necropsy studies have suggested a direct relation between the formation of thrombus and rupture of atherosclerotic plaques in ischaemic events. The causes of plaque rupture are not known with certainty. ${ }^{10}$ After exposure to thrombogenic stimuli active compounds derived from platelets and endothelial cells trigger the blood clotting cascade to form thrombin, and activate the fibrinolytic pathway through the release of tissue plasminogen activator and urokinase type plasminogen activator. Thrombin will be neutralised by antithrombin III, forming complexes with thrombin, which can be assayed in plasma as evidence of activation of the coagulation system.

An increase of specific cross linked fibrin degradation products ( $D$ dimer) in plasma is direct evidence of the thrombolytic process. 
In this context thrombosis and thrombolysis seem to be dynamic and simultaneous processes influencing each other. ${ }^{11}$ Products derived from the activation of both the clotting and fibrinolytic mechanisms have been measured in patients with acute myocardial infraction and with stable and unstable angina. ${ }^{12-14}$ We studied the release of tissue plasminogen activator, urokinase type plasminogen activator, tissue plasminogen activator inhibitor-1, and von Willebrand factor. Although normal volunteers did not receive any drugs other variables were comparable among groups. Total tissue plasminogen activator (free and bound to tissue plasminogen activator inhibitor-1) increased threefold in patients with acute myocardial infarction and twofold in patients with unstable angina and silent ischaemia. An increase of the fibrinolytic activity was detected in patients with unstable angina and silent ischaemia as evidenced by the increase in $\mathrm{D}$ dimer concentrations. The possibility that released tissue plasminogen activator was neutralised by tissue plasminogen activator inhibitor-1 when the lytic system was already activated should be considered because the activity of tissue plasminogen activator remained unchanged while that of tissue plasminogen activator inhibitor-1 increased in acute myocardial infarction; this trend was also seen in unstable angina and silent ischaemia.

The concentration of von Willebrand factor changed slightly, but its release from endothelial cells could be prevented by the ingestion of $\beta$ blockers. ${ }^{15}$

In contrast to the patients with acute myocardial infarction patients with unstable angina had normal concentrations of thrombin-antithrombin III complexes and significantly raised $\mathrm{D}$ dimer concentrations. This discrepancy is not easy to explain. Several possibilities arise. Firstly, although acute myocardial infarction caused incremental increases in tissue plasminogen activator concentration, its activity measured in plasma was unchanged because it was neutralised rapidly by tissue plasminogen activator inhibitor-1, whose concentrations also increase in acute myocardial infarction. ${ }^{12-13}$ Secondly, the increase in $\mathrm{D}$ dimer concentration during acute myocardial infarction could be prevented by stasis in the completely occluded coronary arteries. In unstable angina or silent ischaemia thrombus is partially occlusive, allowing some degree of flow through the affected artery. Thirdly, there are differences in focal vasoconstriction of epicardial arteries after partial or complete intracoronary thrombus formation. ${ }^{16}$ Finally, there is a continuous thrombosis-lysis cycle in unstable angina and silent ischaemia as residual thrombi contains active thrombin bound to fibrin, and this is poorly neutralised by antithrombin III. ${ }^{17}$ Haskel et al have described this simultaneous dynamic process of thrombosis and thrombolysis. ${ }^{18}$ Of interest is the observation that there is a relatively small, but highly significant, translesional increase in $\mathrm{D}$ dimer concentration in patients after coro- nary balloon angioplasty. ${ }^{19}$ This provides further support for the relation between thrombosis and thrombolysis after endothelial coronary injury. Kruskal et al have also described an increased concentration of $D$ dimer in patients with unstable angina..$^{20}$ The increase seen in our patients with unstable angina and silent ischaemia, however, could have originated outside the coronary arteries and been induced by bed rest. The $\mathrm{D}$ dimer concentration in patients with episodes of silent ischaemia were not different from those in patients with unstable angina, whose blood was drawn at admission to the intensive care unit.

Compared with patients with unstable angina and silent ischaemia, those with acute myocardial infarction had higher plasma concentrations of thrombin-antithrombin III complexes, confirming the previous report of Munkvad et al. ${ }^{19}$ Thrombin formation depends on the thrombogenicity of the injured area. A subocclusive mural thrombus seems to contain more thrombin adsorbed to fibrin and is more thrombogenic. ${ }^{17}$ Only six of the 12 patients admitted with unstable angina developed silent ischaemia, which could be because the rigid inclusion criteria produced a small but homogeneous group. Although 12 patients with unstable angina were followed up, only six had silent ischaemia, and this is a limit of the study.

Our findings suggest that cycles of thrombosis and thrombolysis are important in silent ischaemia that is not provoked by stress testing (an important limitation in other studies) ${ }^{21}$ and is detected immediately-just as they are in unstable angina at rest.

We thank Dr Ricardo Glancszpigel for the statistical analyses and Dr Bill Harris for his review of the typescript.

1 Fuster V, Chesebro JH. Mechanism of unstable angina. N Engl F Med 1986;315:1023-5.

2 Deanfield JE, Masseri A, Selwyn AP, Ribero P, Chierchia S, Kriker S, Morgan M. Myocardial ischaemia during daily life in patients with stable angina: its relation to symptoms and heart rate changes. Lancet 1983;ii:753-8.

3 Bonow RO, Bacharach SL, Green MV, Lafreniere RL, Epstein SE. Prognostic implication of symptomatic versus asymptomatic (silent) myocardial ischaemia and in asymptomatic patients with angiographically documented coronary artery disease. Am f Cardiol 1988; 60:776-83.

4 Gottlieb SO, Weisfeldt ML, Ouyang P, Mellits ED, Gerstenblith G. Silent ischemia as a marker for early unfavorable outcomes in patients with unstable angina. N Engl ₹ Med 1986;314:1214.

5 Krucoff MW, Wagner NB, Pope JE, Morata DM, Jackson YR, Bottner RK, et al. The portable programmable microprocessor-driven real-time 12-lead electrocardiographic monitor: preliminary report of a new device for graphic monitor: preliminary report of a new device for silent coronary reocclusion. Am $f$ Cardiol 1990;65: 143-8.

6 Thompson J. Blood coagulation and haemostatis. A practical guide. 3rd ed. London: Churchill Livingstone, 1985.

7 Laurell CB. Quantitative estimation of proteins by electrophoresis in agarose gel containing antibodies. Anal trophoresis in agarose
Biochem 1966;15:45-52.

8 Macfarlane DE, Stibble J, Kirby EP, Zucker MB, Grant RA, McPherson J. A method of assaying von Willebrand RA, McPherson J. A method of assaying von Willebrand
factor (Ristocetin cofactor). Thrombosis et Diathesis factor (Ristocetin cofactor).

9 Myerburg RJ, Kessler KM, Mallon SM, Cox MM, de Marchena E, Interian A Jr. Life-threatening ventricular arrhytmias in patients with silent myocardial ischemia due to coronary artery spasm. N Engl $f$ Med 1992; 326: $1451-5$.

10 Gertz SD, Roberts WC. Hemodinamic shear force in rupture of coronary arterial atherosclerotic plaque. $\mathrm{Am} \mathcal{F}$ Cardiol 1990;66:1368-72. 
11 Chesebro JH, Fuster V. Dynamic thrombus and thrombolysis. Role of antithrombins, Circulation 1991;83: 1815-17.

12 Aznar J, Estelles A, Tormo G, Sapena P, Tormo V, Blanch $S$, et al. Plasminogen activator inhibitor activity and other fibrinolytic variables in patients with coronary and other fibrinolytic variables in patients
artery disease. Br Heart $₹ 1988 ; 59: 535-41$.

13 Zalewski A, Shi Y, Nardone D, Bravette B, Weinstock P, Fischerman D, et al. Evidence for reduced fibrinolytic in

14 Theroux P, Latour JG, Leger-Gauthier C, De Lara J. Fibrinopeptide $\mathrm{A}$ and platelet factor levels in unstable angina pectoris. Circulation 1987;75:156-62.

15 Pina Cabral JM, Cunha Monteiro A, Sousa Dias MC Andrade JA. Effect of propanolol, barbiturate anesthesia and splenectomy on factor VIII:C and plasminogen activator release induced by DDAVP: an experimental study on the dog. Thromb Haemost 1989;62:784-7.

16 Zeiher AM, Schchinger V, Weitzel SH, Wollschlager $\mathrm{H}_{\text {, }}$ Just $H$. Intacoronary thrombus formation causes focal vasoconstriction of epicardial arteries in patients with coronary artery disease. Circulation 1991;83:1519-25.

17 Chesebro $\mathrm{JH}$, Fuster V. Thrombosis in unstable angina. N Engl f Med 1992;327:192-4.

18 Haskel EI, Prager NA, Sobel BE, Abendschein DR. Relative efficacy of antithrombotin compared with antiplatelet agent in acelerating coronary thrombolysis and preventing early reocclusion.

Munkvad S, Jespersen J, Gram J, Kluft C. Interrelationship between coagulant activity and tissuetype plasminogen activator (t-PA) system in acute ischemic heart disease. Possible role of the endothelium. f Intern Med 1990;228:361-6.

20 Kruskal JB, Commerford PJ, Franks J, Kirsch RE. Fibrin and fibrinogen-related antigens in patients with stable and unstable coronary artery disease. $N$ Engl $\mathcal{f} \mathrm{Med}$ 1987;317:1361-5.

21 Romero F, Rosano GM, Martuscefli E, Valente A, Reale A. Unstable angina: role of silent ischemia and total ischemic time (silent plus painful ishuemia), a follow-up. 7 Am Coll Cardiol 1992;19:1173-9. 